\title{
References
}

Aghion, P. and P. Howitt (1997), Endogenous Growth Theory, Cambridge, Mass., MIT Press.

Alic, John (2001), 'Post industrial technology policy', Research Policy, 30, 873-89.

Allen, D. and E. Bazan (1990), 'Value-added contribution of Pennsylvania's Business Incubators to Tenant Firms and Local Economies', Report prepared for Pennsylvania Department of Commerce, Pennsylvania State University, PA.

Almeida, P. and B. Kogut (1999), 'Localization of knowledge and the mobility of engineers in regional networks', Management Science, 45(7), 905-18.

Archibugi, Daniele, Jeremy Howells and Jonathan Michie (1999), Innovation Policy in a Global Economy, Cambridge, UK: Cambridge University Press.

Audretsch, D. B. and M. P. Feldman (1996), 'R\&D Spillovers and the Geography of Innovation and Production', American Economic Review, 86(13), 630-40.

AURP (2003), 'University research park profile', Rockville, MD: Association Research Park Inc., January.

Barker, M. (1996), 'Modalities of U-I Cooperation in the APEC Region, Country Report for Canada', Report prepared for the Association of Universities and Colleges in Canada, August.

Berglund, Dan (1998), 'SSTI weekly digest', Columbus, Ohio: State Science and Technology Institute, website accessed February 6, http://www.ssti.org.

Berglund, Dan and Chris Coburn (1995), Partnerships: A Compendium of State and Federal Cooperative Technology Programs, Columbus, $\mathrm{OH}$, Battelle Labs.

Bergman, Edward, David Charles and Pim den Hertog (2001), 'In pursuit of innovative clusters', in Bergman et al. (eds), Innovative Clusters. Drivers of National Innovation Systems, Paris: OECD, pp. 405-19.

Betz, Frederick (1994), 'Basic research and technology transfer', International Journal of Technology Management, Special Issue on Technological Responses to Increasing Competition, 9, (5-6-7), 784-96.

Biggart, N. and M. Guillen (1999), 'Developing difference: social organization and the rise of the auto industries of South Korea, Taiwan, Spain, and Argentina', American Sociological Review, 64, 722-47.

Bradshaw, Ted and Edward Blakely (1999), 'What are the third-wave state 
economic development efforts? From incentives to industrial policy', Economic Development Quarterly, 13(3), 229-44.

Bresnahan, Timothy and Alfonso Gambardella (2004), 'Old economy inputs for new economy outcomes: what have we learned?', in Timothy Bresnahan and Alfonso Gambardella (eds), Building High-Tech Clusters: Silicon Valley and Beyond, Cambridge: Cambridge University Press, pp. 331-58.

Brouard, F., T. Chamberlin, J. Doutriaux and J. de la Mothe (2004), 'Firm Demographics in Silicon Valley North', in L.V. Shavinina (ed.), Silicon Valley North, A High-tech Cluster of Innovation and Entrepreneurship, Amsterdam, Oxford: Elsevier, pp. 57-84.

Callon, M. (1992), 'Dynamics of techno-economic networks' in R. Coombs, P. Saviotti and V. Walsh (eds), Technological Change and Company Strategies: Economic and Sociological Perspectives, London: Harcourt Brace Jovanovich, pp. 72-102.

Canadian Encyclopedia The (1988), Edmonton, Alberta, Canada: Hartig Publishers Ltd, second edition.

Canadian Newspaper Services International (1997), The Blue Book of Canadian Businesses, Ontario: Canadian Business Resource.

Casalet, M. (2000), 'The institutional matrix and its main functional activities supporting innovation', in M. Cimoli, Developing Innovation Systems. Mexico in a Global Context, London and New York: continuum.

Casas, Rosalba (1985), El Estado y la politica de la ciencia en México, ILS UNAM, México.

Casas, Rosalba, Rebeca de Gortari and Ma. Josefa Santos (2000), 'The building of knowledge spaces in Mexico: A regional approach to networking', Research Policy, 29(2), 225-41.

Cassiolato, J.E. and Helena Lastres (1999), Globalizaçao \& Inovaçao Localizada. Experiências de Sistemas Locais no Mercosul, IBICT-MCT, Brasilia, Brazil.

Castells, Manuel (1999), The Information Era: Economy, Society and Culture. Vol. 1: The rise of the Network Society, Oxford and Malden, MA: Blackwell Publishers.

Castells, Manuel and Peter Hall (1994), Technopoles: Mines and Foundries of Information Economy Technopoles of the World: The Making of the 21st Century Industrial Complexes, London: Routledge.

Chandler, Jr., A.D. (1997), The Visible Hand, Cambridge, Massachusetts: Harvard University Press.

Chrisman, James J. (1994), Economic Benefits Provided to the Province of Alberta by the Faculty of the University of Calgary, report prepared for Langford C.H., VP (Research), University of Calgary, September.

Cimoli, M. (2000), Developing Innovation Systems. Mexico in a Global Context, Science, Technology and International Political Economy Series, 
edited by John de la Motte, London and New York: Continuum.

Conacyt (2004), 'Informe general del estado de la ciencia y la tecnología en México', October, México, 274pp, www. conacyt.mx.

Cooke, Philip (2004), 'Regional innovation systems: an evolutionary approach', in Philip Cooke, Martin Heidenreich and Hans-Joachim Braczyk (eds), Regional Innovation Systems: The Role of Governance in a Globalized World, second edition, London, New York: Routledge.

Cooke, Philip, Mikel Gomez Uranga and Goio Etxebarria (1991), 'Regional Innovation Systems: Institutional and Organizational Dimensions', Research Policy, 26, 475-91.

Cooke, Philip, Mikel Gomez Uranga and Goio Etxebarria (1998), 'Regional systems of innovation: an evolutionary perspective', Environmental and Planning A, 30, 1563-84.

Cooke, Philip, Patries Berkholt and Franz Thodtling (2000), The Governance of Innovation in Europe: Regional Perspectives on Global Competitiveness, London: Pinter.

Corona, Leonel (1994), 'Hacia la consolidación de las empresas innovadoras', Economía Informa, Facultad de Economía, Universidad Nacional Autónoma de México, October, 232, 6-13.

Corona, Leonel (1997), Cien Empresas Innovadoras en México, MA Porrúa (ed), México.

Corona, Leonel (coord.) (1999), Innovación Tecnológica y Desarrollo Regional, Pachuca, Mexico: Universidad Autónoma del Estado de Hidalgo.

Corona, Leonel (2001), Innovación y Región. Empresas Innovadoras en los Corredores Industriales de Querétaro y Bajío, Querétaro, México: UAQ.

Corona, Leonel (2002), Teorías Económicas de la Innovación Tecnológica, México: CIECAS-IPN.

Covarrubias-Gaitán, Francisco (2000), 'Prospectivas de la urbanización en la Ciudad de México', El Mercado de Valores, Nacional Financiera, México, 4/Abril, pp. 3-19.

CREDEQ (2000), 'Répertoire des enterprises ayant bénéficié des services du CREDEQ', Janvier, Quebec, Qc, Canada.

Croft, W.D. (1997), 'Calgary, Canada, a model Technopole', presentation made at Technopolis 97, Ottawa, 10 September.

Davelaar, E. J. (1991), Regional Economic Analysis of Innovation and Incubation, Avebury: Gower.

David, P.A. (1975), Technical Choice, Innovation, and Economic Growth, New York: Cambridge University Press.

DeVol, Ross (1999), America's High-Tech Economy: Growth, Development, and Risks for Metropolitan Areas, California: Milken Institute.

Donnelly, Brian (1996), US Research Parks and their Role in Technological Entrepreneurship, paper presented at the INFORMS Conference, Atlanta, 
Georgia, 6 November.

Dorfman, N. (1983), 'Route 128: The development of a regional high-tech economy', Research Policy, 12, 296-316.

Doutriaux, Jérôme (1992), 'Emerging high-tech firms: how durable are their comparative start-up advantages?', Journal of Business Venturing, 7(4), 303-22

Doutriaux, Jérôme (1998), 'Canadian science parks, universities, and regional development', in John de la Mothe and Gilles Paquet (eds), Local and Regional Systems of Innovation, Boston, Mass.: Kluwer Academic Publishers, pp. 303-24.

Doutriaux, Jérôme (1999), 'Technology incubation in Canadian science parks: two case studies', in L. Corona (coord.), 'Experiencias, retos y oportunidades regionales en la innovación tecnológica', Universidad Autonoma del Estado de Hidalgo, Pachuca, Mexico, 14-15 November, 357-69.

Doutriaux, Jérôme, (2000), 'Private sector financed research activities at universities', in J.A. Holbrook and D.A. Wolfe (eds), Innovation, Institutions, and Territory, Regional Innovation Systems in Canada, Montreal: McGill-Queen's University Press, pp. 93-123.

Doutriaux, Jérôme (2003), 'University-Industry Linkages and the Development of Knowledge Clusters in Canada', Local Economy, 18(1), 63-79.

Economist Intelligence Unit (2005), 'The World in 2005', The Economist, UK. Economist (The) (2004), 'The peso crisis, ten years on Tequila slammer', 29 December, Mexico City. From The Economist print edition.

Edquist, C. (ed.) (1997), System of Innovation, Technologies, Institutions, and Organizations, London: Pinter.

Etzkowitz H. and Loet Leydesdorff (1998), 'A triple helix of university-industry-government relations', Industry \& Higher Education, August, 12(4), 197-201.

Europa World Yearbook, Volume II The (2003), 'The United States of America: introductory survey', London and New York: Europa Publications, pp. 4401-19.

FP Markets, Canadian Demographics (2001), Toronto, Ontario: Financial Post Publications.

Freeman, Chris (1999), 'Innovation systems: city-state, national, continental and sub-national', in J.E. Cassiolato and Helena Lastres (eds), Globalizaçao \& Inovaçao Localizada. Experiências de Sistemas Locais no Mercosul, Brazil: IBICT-MCT Brasília, Brazil.

Gacel-Ávila, Jocelyne (2001), La Internacionalización de las Universidades Mexicanas. Políticas y Estrategias Institucionales, ANUIES.

Globe and Mail, The (2000a), Toronto, Ontario, 24 November. 
Hansen, M.T., H.W. Chesbrough, N. Nohria and D.N. Sull (2000), 'Networked Incubators, Hothouses of the New Economy', Harvard Business Review, September-October.

Harms, D., R. Girard and B. Peterman (2001), 'Creating Economic Activity: University of Saskatchewan example', UST, October.

Industry Canada (2001), 'The ICT Sector in Canada', August, Industry Canada, http://strategis.ic.gc.ca/pics/it/sp1199e.pdf.

Industry Canada (2004), 'ICT Sector Intramural R\&D Expenditures, 2004 Intentions', http://strategis.ic.gc.ca/epic/internet/inict-tic.nsf/en/ h_it05385e.html, consulted on 25 February, 2005.

INEGI (2001), XII Censo General de Población y Vivienda 2000, México.

IRAP (2000), 'Performance report 1999-2000: building capacity in the Canadian system of innovation', August 2000, p. 19, http://irap-pari.nrccnrc.gc.ca/pr99-c.pdf.

Keeble, David and Frank Wilkinson (2000), 'High-technology SMEs, regional clustering and collective learning: an overview', in David Keeble and Frank Wilkinson (eds), High-Technology Clusters, Networking and Collective Learning in Europe, Burlington, US: Ashgate, pp. 1-20.

Klein, Hans (2001), 'Technology push-over: defense downturns and civilian technology policy', Research Policy, 30, 937-51.

Kogut, B. (ed.) (1991), 'Country capabilities and permeability of borders', Strategic Management Journal, 12, 33-47.

Krugman, Paul (1991), 'Increasing returns in economic geography', Journal of Political Economy, 99, 483-99.

Landry, Julie (2000), 'Econets suffer from fatal flaw', Redherring, 27 November.

Langford, Cooper H., J.R. Wood and T. Ross (2002), 'Origins and structure of the Calgary Wireless Cluster', University of Calgary, Faculty of Communication and Culture September, http://www.thecis.ca/ working_papers1.html

Larson, Charles F. (2001), 'U.S. industry moderates its R\&D spending', Research-Technology Management, 44(4), July-August, pp. 2-4.

Laurin, Annie (2001), 'Pleins feux sur Québec, une capitale à vocation technologiquie', Le Soleil, Quebec, Canada, 7 October.

Lavrow, M. and S. Sample (2000), 'Business incubation, trend or fad?', University of Ottawa, E-MBA program report, October.

Lederman, Daniel, William F. Maloney and Luis Servén (2005a), 'Lessons from NAFTA for Latin America and the Caribbean Countries', chapter 1 in Lessons from NAFTA for Latin America and the Caribbean, The World Bank, pp. 1-26.

Lederman, Daniel, William F. Maloney and Luis Servén (2005b), 'Innovation in Mexico: NAFTA is not enough', chapter 6 in Lessons from NAFTA for 
Latin America and the Caribbean, The World Bank, pp. 247-88.

Leydesdorff, L. and Henry Etzkowitz (1998), 'The triple helix as a model for innovation studies', Science and Public Policy, June, 25(3), 195-203.

Lugar, Michael and Harvey Goldstein (1991), Technology in the Garden: Research Parks and Regional Economic Development, Chapel Hill, NC: The University of North Carolina Press.

Lukas, R. (1988), 'On the mechanics of economic development', Journal of Monetary Economics, 22(1), 3-42.

Marshall, Alfred ([1890], 1961), Principles of Economics, London: Macmillan.

Martínez Rizo, Felipe (2000), Nueve Retos para la Educación Superior. Funciones, Actores y Estructuras, ANUIES, Mexico.

Master, J.W. and C. Reichert (2000), 'Calgary, Heart of the New West', presentation by J.W. Master, president and CEO of Calgary Technologies Inc., and by Charles Reichert, Director Infoport, July.

Mian, Sarfraz (1994), 'U.S. university sponsored technology incubators: an overview of management, policies and performance', Technovation, Elsevier Advanced Technology, 14(8), 515-28.

Mian, Sarfraz (1996), 'Assessing value-added contributions of university technology business incubators to tenant firms', Research Policy, 25, 325-35.

Mian, Sarfraz (1997), 'Assessing and managing the university technology business incubator: an integrative framework', Journal of Business Venturing, 12(4), 251-340.

Mian, Sarfraz and Walter Plosila (1996), 'Emerging models of state programs in technology and enterprise development: the US experience', INFORMS annual conference, Atlanta.

Mian, Sarfraz and Walter Plosila (1997), 'Mechanisms for commercializing university research: a study of selected university programs in the U.S.', paper presented at The Sixth International Conference on Management of Technology, Gothenburg, Sweden.

Minnesota Office of Science and Technology (1988), State Technology Programs in the United States - 1988. Prepared by Minnesota Department of Trade and Economic Development in Cooperation with LFW Management Associates, Alexandria, VA.

Moulaeert, Frank and Faridah Djellal (1995), 'Information technology consultancy firms: economies of agglomeration from a wide-area perspective', Urban Studies, 323(1), 105-122.

Mowery, David and Nathan Rosenberg (1993) 'The U.S. National Innovation System', in Richard Nelson (ed.), National Innovation Systems, New York: Oxford University Press.

Musalem, Omar (1989), Innovación tecnológica y parques científicos. 
Ensayos sobre ciencia y tecnología, México: Nacional Financiera.

National Academy of Engineering (1988), The Technological Dimensions of International Competitiveness, Washington, DC.

National Governors' Association (2002), New York Profile of the State Economy.

National Science Board (2000), National Science and Engineering Indicators 2000, National Science Foundation, Washington, DC: Government Printing Office.

National Science Board (2004), Science and Engineering Indicators 2004, National Science Foundation, Arlington, VA, USA.

National Science Foundation (1998), Venture Capital Investment Trends in the United States and Europe, NSF 99-303.

National Science Foundation (2000), Science and Technology Pocket Book, NSF.

National Science Foundation (2001), Science and Engineering Indicators 2000, NSF.

National Science Foundation (2002), State Science and Technology Indicators, National Science Foundation.

National Science Foundation (2004), Science and Engineering Indicators, Washington DC: Government Printing Office.

National Science Foundation (NSF) and National Science Board (NSB) (1996), Science and Engineering Indicators, Washington DC: Government Printing Office.

National Venture Capital Association (2005), website accessed February 1, http://www.nvca.org/nvca7_29_03.html.

Nelson, Richard (ed.) (1993), National Innovation Systems: A Comparative Analysis, New York: Oxford University Press.

NY State Science \& Technology Foundation (1992), New York State Centers for Advanced Technology Program: Evaluation, Past Performance and Preparing for the Future, Menlo Park: CASRI International.

OECD (1997a), The Measurement of Scientific and Technological Innovation Data. Proposed Guidelines for Collecting and Interpreting Technological Innovation Data: OSLO MANUAL, European Commission /Eurostat.

OECD (1997b), Technology Incubators, Nurturing Small Firms, Paris: OECD. OECD (1997c), National Innovation Systems, Paris: OECD.

OECD (1999), Business Incubation. International Case Studies, Paris: OECD.

OECD (2001a), Innovative Clusters: Drivers of National Innovation Systems, Paris 15 July, OECD.

OECD (2001b), Innovative Network: Cooperation in National Innovation Systems, Paris: OECD.

OECD (2001c), Innovative People. Mobility of Skilled Personnel in National Innovation Systems. Science and Innovation, Paris: OECD. 
OECD (2002a), Benchmarking Industry-Science Relationships, Paris: OECD. OECD (2002b), Dynamising National Innovation Systems, Paris: OECD.

OECD (2003a), Turning Science into Business: Patenting and Licensing at Public Research Organisation, Paris: OECD.

OECD (2003b), OECD Science, Technology and Industry Scoreboard 2003, Paris: OECD.

OECD (2003d), Economic Survey of Mexico, Policy Brief November. Paris: OECD.

OECD (2004a), Science and Innovation Policy. Key Challenges and Opportunities, Meeting of the OECD Committee for Scientific and Technology, Policy at Ministerial Level, 29-30 January, Paris: OECD.

OECD (2004b), Science and Technology Statistical Compendium, Meeting of the OECD Committee for Scientific and Technology, Policy at Ministerial Level, 29-30 January, Paris: OECD.

OECD (2004c), Main Science and Technology Indicators 2004/2, Paris: OECD.

OECD (2004d), OECD Science, Technology and Industry Outlook, Paris: OECD.

OECD (2004e), Territorial Reviews: Mexico City, October, Policy Brief, Paris: OECD.

OECD and CERI (2004), National Review on Educational R\&D Examiners, Report on Mexico, Paris: OECD.

Ottawa Business Journal (2002), 18 February.

Ottawa Economic Development Corporation, '1998 Ottawa facts', Ottawa, Canada.

Partida Romo, Raquel (1999), 'Impacto e Innovación tecnológica de la industria electrónica en Guadalajara, en la década de los noventa', in Leonel Corona (coord.), Innovación tecnológica y desarrollo regional, Universidad Antónoma del Estado de Hidalgo, Pachuca, Mexico, pp. 189-208.

Pavitt, K. (1984), 'Sectorial pattern of technical change: toward a taxonomy and a theory', Research Policy, 13, North Holland, 343-73.

Pecyt (2001), Programa Especial de Ciencia y tecnología 2001-2006, SEPConacyt, Mexico, 30 October.

Plosila, Walter (1988), 'Technological innovation: the sub-national government experience in the United States', paper presented at Technology and the City: An International Conference on the Potential of New Technology Enterprises to Regenerate Inner Cities, London.

Plosila, Walter (2004), 'State science and technology-based economic development policy: history, trends and developments, and future directions', Economic Development Quarterly, 18(2), 113-26.

Ponce Ramirez, Luis (1999), 'El sistema regional de ciencia y tecnología', in Corona Leonel (coord.), Innovación Tecnológica y Desarrollo Regional, 
Pachuca, México: UAEH.

Porter, Michael (2001), 'Strategy and the internet', Harvard Business Review, March, pp. 63-80.

Porter, Michael and Scott Stern (2002), 'National Innovation Capacity', in Porter et al. (eds), The Global Competitiveness Report 2001-2002, New York: Oxford University Press, pp. 102-119.

Reamer, Andrew, Larry Icerman and Jan Youtie (2003), 'Technology transfer and commercialization: their role in economic development', US Department of Commerce, EDA report number 990607435.

Reséndiz Nuñez, Daniel (2000), Futuros de la Educación en México, Mexico: Siglo XXI.

Rice, M. (1993), 'Intervention mechanisms used to influence the critical success of new ventures: an exploratory study', Unpublished Ph.D. Dissertation, Renssalaer Polytechnic Institute, Troy, NY.

Rifkin, Jeremy (2000), The Age of Access, New York: Jeremy P. Tarcher/ Putman Inc.

Roberts, Edward and Denis Malone (1996), 'Policies and structures for spinning-off new companies from research and development organizations', R\&D Management, 26(1), 17-48.

Rodriguez, J. and M. Villa (1997), 'Dinámica sociodemográfia de las metrópolis latinoamericanas durante la segunda mitad del siglio XX', Natas de Problación, 65, Junio, Santiago de Chile: CEPAL.

Romer, Paul (1986), 'Increasing returns and long-run growth', Journal of Political Economy, 94, October, 1002-37.

Rosenberg, N. (1972), Technology and American Economic Growth, New York: Harper and Row.

Rothwell, Roy (1994), 'Towards the fifth generation innovation process', International Marketing Review, 1(1), 7-31.

Ryan, Vincent (2000), 'After the incubator', Telephony, 20 November, 2000.

Sanz, Luis (2004), 'The future role of science parks in metropolitan science regions', SSES and ESBRI Research Seminar. Stockholm, March. http://www.iasp.ws/information/definitions.

Sanz, Luis and Philip Cooke (2004) 'Regional innovation systems: an evolutionary approach', in Cooke et al. (eds), Regional Innovation Systems: The Role of Governance in a Globalized World, 2nd edn, London, New York: Routledge Press.

Saxenian, Annalee (1994), Regional Advantage: Culture and Competition in Silicon Valley and Route 128, Cambridge, Mass.: Harvard University Press.

Schoonhoven, C.B. and E. Romanelli (eds) (2002), The Entrepreneurship Dynamics: Origins of Entrepreneurship and the Evolution of Industries, Stanford, CA: Stanford University Press.

Shapira, Philip (2001), 'US manufacturing extension partnerships: technology 
policy reinvented', Research Policy, 30, 977-92.

Sherman, Hugh and David Chappell (1998), 'Methodological challenges in evaluating business incubator outcomes', Economic Development Quarterly, 12(4) November, 313-21.

Smilor, R. and M. Gill (1986), The New Business Incubator: Linking Talent, Technology and Know-How, Mass.: Lexington Books.

SSTI Weekly Digest (1997), 'Memorandum of Understanding: Officially Established', USIP, 27 June, State Science and Technology Institute, Ohio.

SSTI Weekly Digest (1998), 'State science and technology institute', Columbus, Ohio, USA, February 6, http://www.ssti.org.

Statistics Canada, Service Bulletin on Science Statistics, Science, Innovation and Electronic Information Division, 88-001-XIE, Ottawa, Canada, various issues.

Statistics Canada, Provincial Gross Domestic Product by Industry, Catalog 15203-XPB, Ottawa, Canada, various issues.

Statistics Canada (1999), Education Indicators in Canada, catalog 81-582XIE.

Statistics Canada, CANSIM, Ottawa, Canada.

Storper, Michael (1997), 'The regional world, territorial development in a global economy', New York, London: Guildford Press.

Stuart, T. and O. Sorenson (2002), 'The geography of opportunity: spatial heterogeneity in founding rates and the performance of biotechnology firms', Research Policy, 32, 229-53.

Stuart, T. and O. Sorenson (2003), 'The geography of opportunity: spatial heterogeneity in founding rates and the performance of biotechnology firms', Research Policy, 32, 229-53.

Tonatzky, L., Y. Batts, N. McCrea, M. Lewis and L. Quittman (1996), The Art and Craft of Technology Business Incubation, Southern Technology Council, Durham, NC and NBIA, Athens, $\mathrm{OH}$.

Turner, Barry (ed.) (2002), The Statesman's Yearbook: the Politics, Cultures and Economics of the World, London and New York: Palgrave, p. 1731.

Unger, Kurt and Mateo Oloriz (1998), Innovation and Foreign Technology in Mexico's Industrial Development, Mexico, CIDE Num. 117.

Unger, Kurt and Mateo Oloriz (2000), 'Globalization of production and technology', in M. Cimoli, Developing Innovation Systems. Mexico in a Global Context, London and New York: Continuum.

US Census Bureau (2004), 'State and country quickfacts', visited 1 February, 2005, http://quickfacts.census.gov/qfd/states/00000.html.

U.S. Department of Commerce (1997), The Global Context for US Technology Policy, Washington, DC: Office of Science and Technology Policy.

US Dept of Commerce (1997-98), State and Metropolitan Area Data Book, Washington, DC. 
Yin, Robert (1984), Case Study Approach, Beverley Hills, CA: Sage.

Zambrano Plant, Carlos (2001), 'La promoción económica de una región de alto crecimiento industrial: el caso de Nuevo León', El Mercado de Valores, NAFIN, Mexico, November, pp. 31-8.

\section{WEB REFERENCES}

http://cde.itesm.mx/red_directorio.php http://content.calgary.ca/CCA/City+Hall/Business+Units/Customer+Service+ and+Communications/Corporate+Marketing/Municipal+Handbook/+Welc ome+to+Calgary/Industrial+Base.htm\#research percent20and percent20 development

http://irap-pari.nrc-cnrc.gc.ca

http://precarn.ca/Corporate/corporate.cfm

http://strategis.ic.gc.ca/SSG/bo01544e.html, Overview of Biotechnology, 8 August, 2001.

http://strategis.ic.gc.ca/epic/internet/inict-tic.nsf/en/h_it05385e.html http://strategis.ic.gc.ca/pics/it/it05373e.pdf; http://strategis.ic.gc.ca/pics/it/ sp1199e.pdf, The ICT Sector in Canada, August 2001.

http://194.30.15.20/iaspworld/about/fabout.htm, International Association of Science Parks.

\section{Next addresses are http://}

www.accc.ca/english/Colleges/membership_list.cfm

www.agwest.sk.ca/agwest.shtml

www.areadevelopment.com/Pages/Features/Feature11.html

www.aucc.ca/en/aboutindex.html

www.bancomext-mtl.com/invest/vox 128.htm

www.calgarytechnologies.com.

www.canarie.ca/about/about.html.

www.cfyge-prifepei.ipn.mx

www.cihr.ca/

www.city.saskatoon.sk.ca, quick facts, June 2002.

www.conacyt.mx/dat/avance);

www.conacyt.mx/dadrys/directorio/index.html

www.cqib.org

www.cvca.ca Venture Capital Association of Canada

www.entrepreneurship.com

wwww.gov.sask.ca/bureau.stats, Jan 2005

www.gov.sk.ca/econdev/investment/sixsctrs/technology/sector.shtm 
www.gov.sk.ca/soco/faq.htm

www.inegi.gob.mx

www.infostat.gouv.qc.ca

www.innovationplace.com/html/frameset.html

www.mic.gouv.qc.ca/PME-REG/regions/, Quebec Government data.

www.nce.gc.ca/en/netseng.ht

www.nrc-cnrc.gc.ca

www.ocri.ca

www.ocri.ca/ocrimodel/publications/1204_ottawafacts.pdf

www.oecd.org/department/0,2688,en_2649_34357_1_1_1_1_1,00.html www.parctechno.qc.ca/english/histo.htm

www.researchinfosource.com/top50.html

www.siicyt.gob.mx

www.soco.sk.ca/links/index.html

www.speqm.qc.ca/speqm-fra/cont-quebec-technoregion.html

www.speqm.qc.ca/speqm-fra/cont-quebec-technoregion.html

www.sreda.com/science-city_biotechnology.php

www.statcan.ca. Statistics Canada.

www.statcan.ca/english/census96/apr14/educ.htm.

www.statcan.ca/english/Pgdb/econ05.htm

www.statcan.ca/english/Pgdb/gblec02a.htm

www.techba.com

www.thecis.ca/working\%20papers/Origins\%20and\%20Structure.pdf www.wto.org, International Trade Statistics 2001. 
Leonel Corona, Jérôme Doutriaux, and Sarfraz A. Mian - 9781845428013 Downloaded from PubFactory at $04 / 26 / 2023$ 02:44:14PM 